\title{
近代の大阪および阪神間を中心とした擬木・擬石・擬岩の導入と展開
}

\section{Introduction and Development of Imitation Tree, Imitation Stone and Imitation Rock as Modern Landscape Material in and around Osaka and Hanshinkan Area}

粟野 隆*

Takashi AWANO

\begin{abstract}
This paper aimed to clarify the concrete situation of introduction and development of imitation tree, imitation stone, and imitation rock as modern landscape material in and around Osaka and Hanshinkan area. As the results of documents analysis and field survey, this paper led the following. There are: Imitation tree had introduced into this area around the end of Taisho era. About introducing imitation tree, landscape architect SHIIHARA Hyoichi, Landscape engineer HASHIMOTO Yaezo and KOBAYASHI Kanzan had played an important role. In the early Showa era, imitation tree, imitation stone, and imitation rock were being used widely in residential gardens and public parks in Osaka and Hanshinkan area. Imitation tree were used for garden furniture as arch, bench, bridge, and so on. Imitation stone were used for stone arrangement of waterfall and mound. Imitation rock were used for animal's pasturage exhibition facilities they are monkey mountain and polar bear cage. These were designed and constructed by landscape architect and landscape engineer of the above three. Also, it was found that the modern plutocrat NITTA Chojiro introduced garden furniture made of imitation tree and rock arrangement consisted of imitation stone into his residential garden in Koshien area of Nishinomiya, Hyogo Prefecture.
\end{abstract}

Keywords: imitation tree, imitation stone, imitation rock, modern landscape キーワード: 擬木, 擬石, 擬岩, 近代造園

\section{1. はじめに}

庭園に擬木や擬石を使うというのは，造園の世界では軽視され る傾向があったように思われる。たとえば，造園学者の上原敬二 は，「ここで述べるものは擬岩，擬石，擬木（杭，柱，丸太，板， 切株), 擬竹である。材料は自然物であるが構造が自然ではない。

こうしたものは個人の住宅，庭園に用うべきものではない。前 に述べた材料の真，構造の真にそむくが故である。木材でいえば ベニヤ, 合板, はりつけ物に当たる」1）と，言い切っていること からも良く分かる。

ところが，平成 22 年，琴ノ浦温山荘庭園（和歌山県海南市） が名勝に指定された (同年 2 月 22 日告示)。本庭園の指定説明 2 ) には,「コンクリート製の擬石, 擬木の素材を多用した独特の技法」 すなわち,「自然石の外側にセメント，モルタルを施して，原石よ りもひとまわり大きく, さらに自然の石らしく仕上げた擬石」や, 「木材に似せて造られたコンクリート製の擬木を多用」している 点を，注目す心゙き工夫として評価しているのである。近年の名勝 保護行政では, 当面して保護の措置を講ずべき対象のひとつに「新 しい時代の庭園」を取り上げ，近代の庭園や公園の指定・登録を す寸めている ${ }^{3}$ 。この点も考慮すると，本庭園のように，近代に 至ってわが国の庭園や公園に導入された造園材料（以下，近代造 園材料と呼称）としてのセメント，モルタル，コンクリートを用 いた擬木・擬石・擬岩を構成・意匠した庭園や公園に関する学術 的な研究調査の必要性が生じてきたと考えることも可能である。

以上のような背景もあり，筆者の当面の目標は，近代造園材料 であるセメント，モルタル，コンクリートを施工材料としてでは なく, 意匠材料としての観点から利用した擬木・擬石・擬岩を対 象に，その導入事例の把握，造形意匠上の特徽，製作に関与した 近代造園家・造園技術者の詳細などを解明することである。

擬木・擬石・擬岩に関する主たる先行研究には，左官師か力土 木請負師の服部長七が「たたき」の技術を用いてわが国最初の擬 石を発明し，これを明治 29 年頃に自邸の屋上庭園の飛石や沓脱
石などに用いたことを明らかにした近藤の研究 ${ }^{4}$ ， 大阪を拠点に 活躍した近代の造園技術者・橋本八重三の広告戦略や植物病院事 業など多面的経営展開を明らかにしつつ，そのなかで「橋本式人 造自然木」の一端について考察した橋爪の研究 5), 温山荘庭園の 造園史上の評価にかかわり，日本近代における擬木・擬石の造園 的利用の系譜の概要をまとめた粟野の研究 ${ }^{6}$ )が存在する。

特に粟野論文 ${ }^{6)}$ は, 近代の大阪および阪神間では椎原兵市，小 林観山，橋本八重三を中心として庭園や公園に擬木・擬石が導入 されたことを指摘した。しかしこの論文には当該地域一の擬木の 導入経緯に再検討を要する点が存在し, 上記造園家・造園技術者 が関与した擬木・擬石・擬岩を用いた庭園・公園事例も詳細まで は把握していなかった。

以上の点をふまえて本論文では，近代の大阪および阪神間を中 心とした擬木の導入経緯を精査しつつ, 擬木・擬石・擬岩を利用 した事例の詳細を把握し，その導入や製作に関与した近代造園 家・造園技術者の取り組みを明確化することを目的とした。

なお，本論文で対象とした擬木・擬石・擬岩は，造園資材に利 用された模擬木材 (自然木・加工材) や模擬岩石であり，建築材 料として利用されることの多い研ぎ出しあるいは水研ぎ仕上など による人造石や，鋳型に流し込んで製作された青銅製などによる 金物の擬木は研究対象から外した。研究方法は文献調查と残存事 例の現地調査によった。

\section{2. 大正末期における擬木の導入事情}

大阪および阪神間における擬木の導入事情については，諸説が 存在する。具体的には，イ：キューバでフランス式の擬木工法を 中沢考のもとで習得した松村重が大正初期に帰国し，当時大阪市 公園課長であった椎原兵市に伝えたという説（しかし椎原は関心 を示さなかったため, 松村は東京市公園課長の井下清に伝えたと いう） 1)，ロ：キューバから帰国した中沢考が大正 15 年頃に椎原 兵市を訪ね, 大阪市内の公園に擬木を使ってはどうかと勧め, 大

*東京農業大学地域環境科学部造園科学科 
阪の住吉で造園業を営む橋本八重三（橋本庭園工務所）にこれを 紹介して，椎原が橋本を助成したのが始まりとする説 ${ }^{7)}$ ，またそ の 2 説をあわせ，八：大正初期に椎原はまず松村重から紹介を受 け, その後大正 15 年頃に中沢からも勧められたと理解したもの6) である。このように，文献によって記載が異なり，導入経緯が不 明確なのである。

しかしイと八については，椎原が大阪市技手になったのが大正 9 年, 公園課長になったのが大正 13 年 8 ) であるため,「大正初期 に伝えた」という点で矛盾していることが分かる。また，元東京 都技師・村松善豊によれば，井下が大正 15 年に欧米視察の際に 擬木を知り，松村に擬木製作の必要性を述へ，研究に着手させた 9) ことを指摘し，時期的にも井下から松村への情報伝達の相違に おいても松村が椎原に擬木づくりを勧めたという点に疑問が残る。

以上の導入事情に関する検討から，本稿では口説を支持するも のとする。なお，口説は芦屋の造園技術者・小林観山（小林六合 園）によるものであり，小林も同じ頃に横浜の野毛山公園でみた 擬木にヒントを得て, 独自の立場で研究試作を開始した人物 7)で ある。したがって大阪および阪神間では, 大正 15 年頃から椎原・ 橋本・小林の 3 氏を中心に擬木製作が始められたと理解できる。

\section{3. 昭和初期における擬木 - 擬石 ·擬岩の造園的利用とその展開}

\section{（1）椎原兵市による住宅・別荘庭園への擬木の導入}

椎原は大阪市公園課長という要職にあったが，その傍ら，住宅 や別荘の庭園設計を手掛け，そこで得た手法や実例もとに，昭和 3 年に『庭園の設計と其実例』10）をまとめた。本書は，椎原が手 掛けた京阪神の郊外住宅を中心とし，なかには東京に所在する実 作も取り上げつつ，若干の理想案を加えた 30 庭園を掲載したも のである。本書から擬木を用いたものは 10 例を確認することが できた（表一1）11）あわせて，10 例のうち 4 例に添付された見 積書が橋本庭園工務所（3 例） と小林六合園（1 例）による作成 であったことから，椎原は大正 15 年頃から昭和 3 年までに，橋 本や小林と協働で住宅および別荘庭園に擬木を用い始めていたこ とが判明する。この頃擬木は, バラ棚, 腰掛, 花壇縁石, 池の乱 杭，展望台など，さまざまな庭園施設に導入されていたことがう かがえる。ただし本文献からは，各庭園施設の擬木の具体的な構 造・意匠は不明である。

\section{（2）橋本八重三による擬木の商品開発}

昭和初期における大阪および阪神間の擬木の詳細は，橋本八重 三の諸活動から把握寸ることができる。すでに先行研究 5) が指摘 するように, 橋本は昭和 5 年刊行の自著『植木屋の裏おもて』12) で, 「鉄筋混凝土にセメントの外皮をかぶせて樹皮や木目を擬刻し て，樹皮と同様の着色を施した」という「橋本式人造自然木」を 開発したことを述べている（図一1）。

橋本は当初, 樹皮の表面仕上は庭師としては容易くできたが,

\section{表一1 『庭園の設計と其実例』掲載の擬木を用いた庭園}

\begin{tabular}{|c|c|c|}
\hline 名 称 & 規 模 & 擬木施設 \\
\hline リリーポンドを持つ庭 & 180 坪 (建坪32坪) & バラ棚 (コンクリート模擬天然木製) \\
\hline 細長い敷地を持つ庭 ※1 & 155坪 (建坪38坪5合) & 長腰掛 (人造自然木製) \\
\hline  & 357坪 (建坪85坪) & 綠門 (人造自然木製) \\
\hline 和洋両式を有つ庭 (その二) & 520 坪 (建坪 120 坪) & 花壇盆栽用鉢 (コンクリート木目入り仕上) \\
\hline 和洋両式を有つ庭 (その三) & 410 坪 (建坪47坪) & 綠門 (コンクリート模擬人造天然木製) \\
\hline 或る医師の庭 ※2 & 530坪(建坪90坪) & 花壇縁石 (人造自然木型) \\
\hline 林泉式の庭 (その一) ※1 & 240 坪(建坪26坪) & 塀 (コンクリート造り模擬杉皮張) \\
\hline 林泉式の庭園(その二) & 300 坪 (建坪49坪) & 乱杭 (人造自然木製) \\
\hline 地形と地物に恵まれた庭 & $\begin{array}{l}\text { 620坪(建坪: 本屋63坪、 } \\
\text { 御茶屋12坪) }\end{array}$ & 展望台 (コンクリート製模擬木材) \\
\hline 泉水を主とする庭 & 1350坪 (建坪95坪) & $\begin{array}{l}\text { 魚釣台(コンクリート製) } \\
(\text { (掲載写真から题木と認定) }\end{array}$ \\
\hline
\end{tabular}

註:「名称」欄に記載された※1は、橋本庭園エ務所が施エした事例で、※2は小林六合園の施エした事 例を示す。
鉄材の屈曲やメタルラス切断といった擬木の骨組製作，メタルラ スへのモルタルの塗着など, 鍛治仕事や左官仕事に苦労したこと を述べている。ただし橋本は，大阪の鉄鋼会社社長の自邸庭園の 仕事を取り，そこで高さ 14 尺の防火兼用の住宅の外囲いをみご と擬木塀で製作，これで成功をおさめ，技術とともに自信も身に つけ，庭園の装飾品として人造自然木製品を開発していった ${ }^{12)}$ 。 昭和 7 年頃の発行と思しき橋本庭園工務所の会社案内力タログ 『庭園の設計・施工案内』13）には，人造自然木製品が商品として 掲載されている (図-2)。その種類もパーゴラ, 四阿, 庭橋（八 ッ橋・土橋・哯橋), 庭井戸, 卓, 腰掛けなど, 特に庭園家具に多 種多様な展開をみせていたことが分かる。商品名も「人造自然木」 としているように，表面を皮付天然木や皮付丸太としたものが多 くを占め, 製材として木目入仕上としたものは塀や八橋など若干 である。

このカタログに掲載された主要な製品の価格をみると，「四阿 (引字形亭) 9 尺 5 寸角 1 棟 $¥ 480.00$ より」, 「庭門 巾 4



図一1 綠廊や階段土留に橋本式人造自然木を用いた 堺・上田邸庭園（出典 :『植木屋の裏おもて』, 昭和 5 年）

\section{表一2『植木屋の裏おもて』に確認された橋本式人造自然木 を導入した庭園および公園等の一覧}

\begin{tabular}{|c|c|c|c|}
\hline 種 別 & 名 称 & 所在地 & 製品の種類 \\
\hline \multirow{21}{*}{\begin{tabular}{c} 
庭 \\
園 \\
住 \\
宅 \\
$\dot{5}$ \\
旅 \\
館 \\
寺 \\
院 \\
\hdashline
\end{tabular}} & たばたや・田中某氏本邸庭園 & 三重県津市 & 詳細不明 \\
\hline & 洋服店主·菱野半次郎本邸庭園 & 大阪豊中 & 詳細不明 \\
\hline & 郵便局長·秋山岩三郎本邸庭園 & 兵庫県大藏村 & 人造自然木門·塀 \\
\hline & 内外綿会社重役·天木繁二郎本邸庭園 & 大阪市若松町 & |人造自然木綠門 \\
\hline & 実業家·楠本利八別邸庭園 & 神戸市長田 & 人造自然木塀 \\
\hline & 製菓所主·石室重助本邸庭園 & 大阪市北畠 & 人造自然木塀 \\
\hline & 洋画家·上田天昭本邸庭園 & 堺市 & 人造自然木綠廊 \\
\hline & 大日本麦酒会社重役- 高橋龍太郎本邸庭園 & 大阪府吹田 & 人造自然木綠廊 \\
\hline & 岩崎男爵別邸庭園 & 東京府 & 詳細不明 \\
\hline & 銀行頭取·足立勘右衛門本邸庭園 & 兵庫県和田山 & 詳細不明 \\
\hline & 実業家·今枝捨市別邸庭園 & 兵庫県宝塚 & 人造自然木露壇 \\
\hline & 実業家·中島一治本邸庭園 & 大阪市松島 & 人造自然木塀 \\
\hline & 実業家·松井輝三本邸庭園 & 大阪市上本町 & 人造自然木綠廊 \\
\hline & 実業家·松井伊助本邸庭園 & 和歌山市新堀 & 人造自然木四阿 \\
\hline & 岩崎男爵家別邸庭園 & 神奈川県箱根 & 詳細不明 \\
\hline & 医師・米田猶次郎本邸庭園 & 奈良県八木町 & 人造自然木塀 \\
\hline & 竹林院庭園(住職·福井良陽依頼) & 奈良県吉野山 & 詳細不明 \\
\hline & 旅館はり半庭園 (乾由之助依頼) & 兵庫県甲陽公園 & 詳細不明 \\
\hline & 医学博士・西浦網一本邸庭園 & 京都市土手町 & 人造自然木門·塀 \\
\hline & 京阪電鉄庶務課長 - 小澤喜之助本邸庭園 & 大阪府枚方 & 人造自然木梱 \\
\hline & 松竹合名社長·白井松次郎別邸庭園 & 兵庫県芦屋 & 人造自然木畘·門 \\
\hline 公 & 大阪毎日新聞社造園 (天王寺支店か?) & 大阪市天王寺公園 & 人造自然木乱杭 \\
\hline$\frac{\text { 園 }}{z}$ & 三笠山公園 (奈良県庁公園課依頼) & 奈良市 & 人造自然木柵 \\
\hline の & 扇町公園 (大阪市役所公園課依頼) & 大阪市扇町公園 & 詳細不明 \\
\hline 他 & 紅野家墓地 (酒造家·紅野平左衛門依頼) & 西宮市 & 詳細不明 \\
\hline
\end{tabular}

註:[名称小欄の人物名は依頼主を示す。「所在地はは植木屋の裏おもて』(昭和5年)の記載のままとした。 

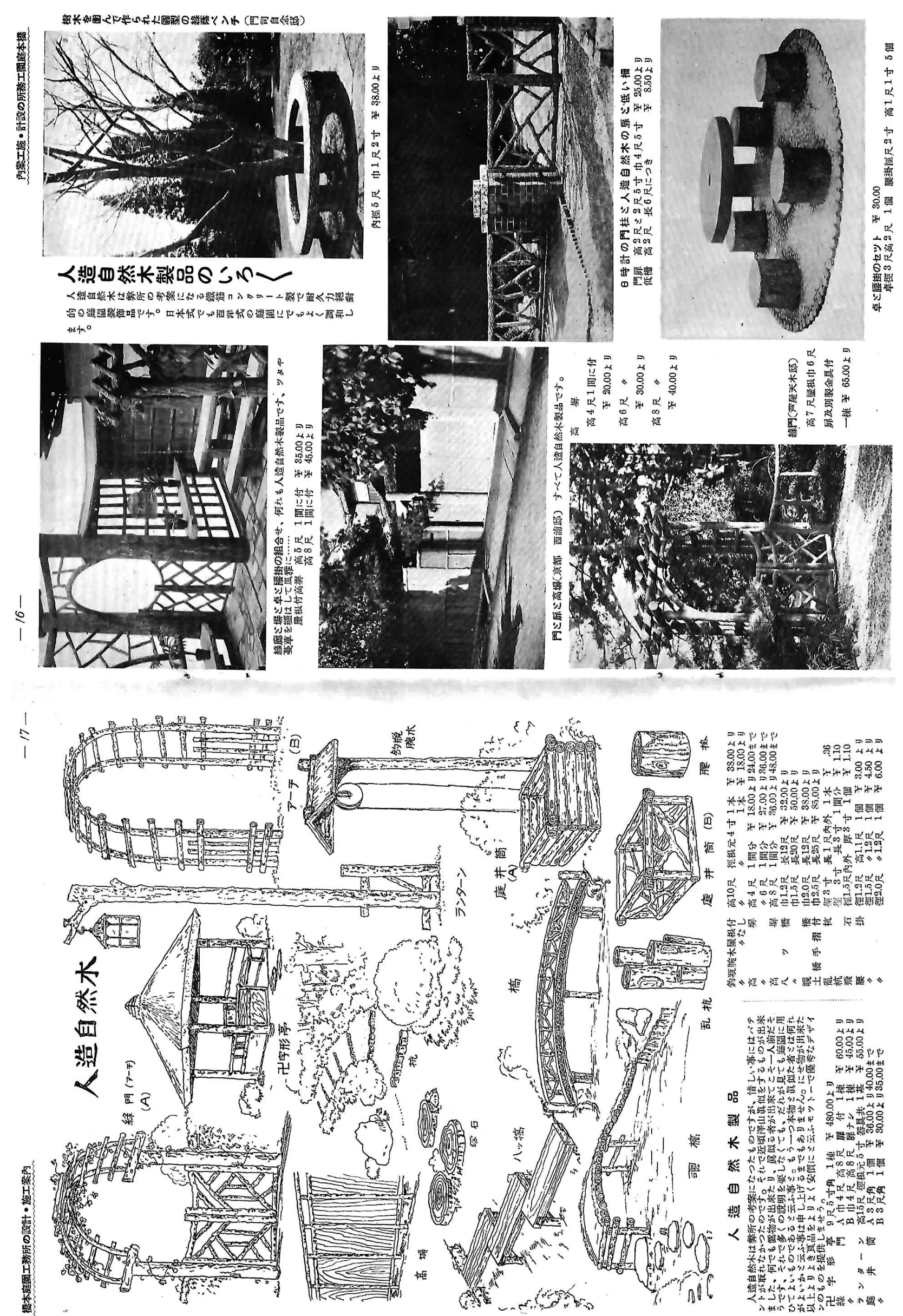

図-2 橋本式人造自然木 (出典 : 『庭園の設計 · 施工案内』, 昭和 7 年頃) 
尺 高 8 尺 扉付 1 棟 $¥ 60.00$ より」,「八ッ橋 巾 1.2 尺 長 さ 12 尺 $¥ 32.00$ より」, 飛石 径 1.5 尺内外 厚さ 3 寸 1 個 $¥ 1.10$ より」などとある。なお，橋本式人造自然木を導入したと 断定できる事例には，吹田の大日本麦酒会社重役・高橋龍太郎邸 庭園，枚方の京阪電鉄支配人 - 小澤喜之助邸庭園，大阪の扇町公 園など 25 例を『植木屋の裏おもて』から確認した。地域別では, 大阪 10 件，兵庫 7 件，奈良 3 件，京都 1 件，和歌山 1 件，三重 1 件，東京 1 件，神奈川 1 件であり，関西を中心に流通していた ことが分かった（表一2）。

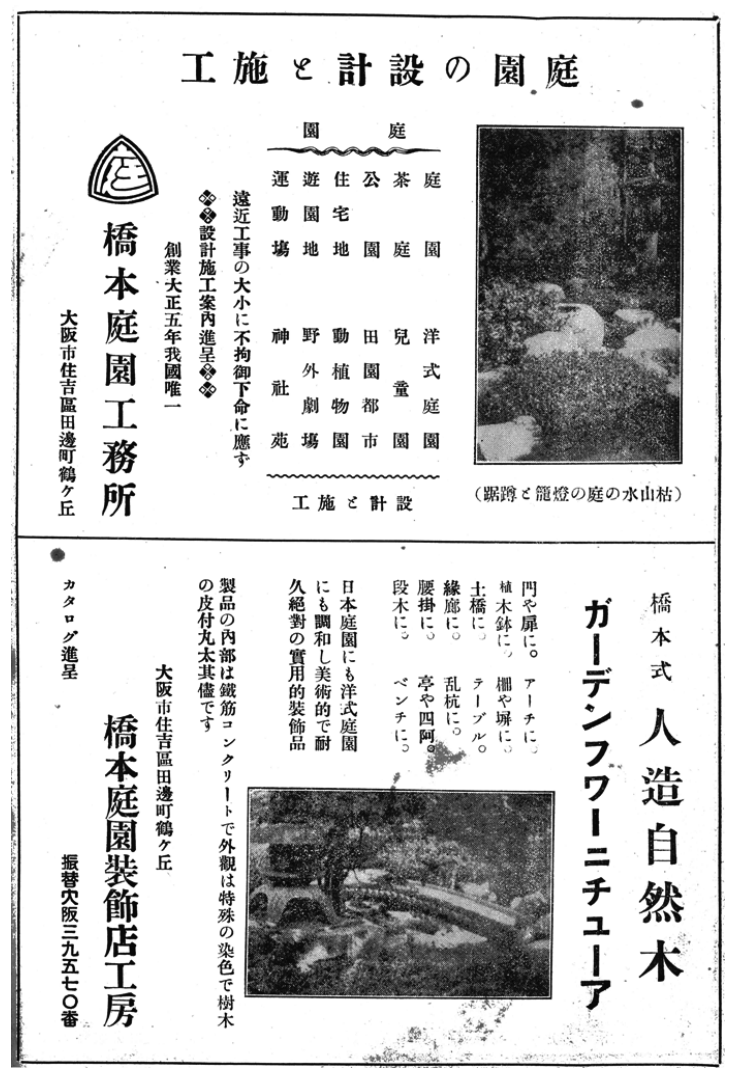

図-3 橋本式人造自然木の商品広告 （出典 : 『全国著名園芸家総覧』初版，昭和 2 年）

\begin{tabular}{|c|c|c|c|c|}
\hline 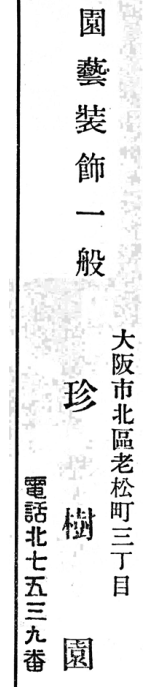 &  & 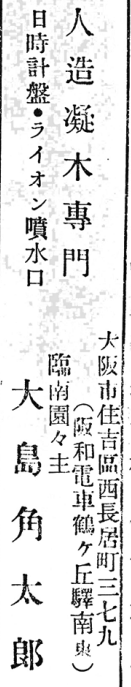 & 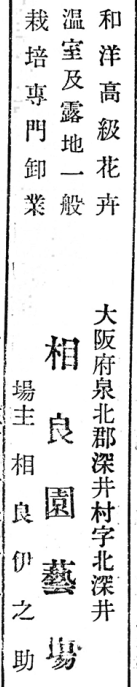 &  \\
\hline
\end{tabular}

図-4 大島角太郎（臨南園）の会社広告（中央部分） （出典 :『全国著名園芸家総覧』第 14 版，昭和 13 年）
これら，橋本式人造自然木の商品化の時期的動向についてであ るが，昭和 2 年に大阪興信所から発行された『全国著名園芸家総 覧』14)を確認したところ, すでに会社広告に「橋本式人造自然木」 という記載があり, 少なくとも昭和 2 年には商品化されていたこ とが判明した (図一3)。したがって橋本は，大正 15 年頃に椎原 から擬木製作を勧められ，わずか 1,2 年のうちに商品化を図っ ていたこととなる。同広告には,「ガーデンフワーニチューア」の 文字が踊り，「日本庭園にも洋式庭園にも調和し美術的で而久絶対 の実用的装飾品」,「製品の内部は鉄筋コンクリートで外観は特殊 の染色で樹木の皮付丸太其儘です」との説明があり, 本製品を大々 的に推奨しようとする橋本の意気込みが読み取れる。しかもこの 当時, 橋本は橋本庭園工務所のほかに, 橋本庭園装飾店工房をも 営んでおり，人造自然木は本工房の担当であったことが分かる。

なお，昭和 13 年発行の『全国著名園芸家総覧』(第 14 版） 15) には，同じく大阪の住吉にて造園業を営む大島角太郎 (臨南園) の会社広告欄にも「人造凝木専門」という記載が確認され（図一 4), 大阪には複数の擬木製作業者が存在していたようである。

（3）西宮 · 甲子園の旧新田邸庭園の擬石の特徵

椎原兵市と橋本八重三が住宅・別荘庭園に導入したのは擬木の みで，擬石は確認できなかった。しかし阪神間において，擬石を 導入した住宅庭園は，近代の郊外住宅地，甲子園に現存事例を確 認した。旧新田邸（現・松山大学西宮温山記念会館）である。

本邸宅は，温山荘庭園に擬木・擬石を多用したことで知られる 実業家・新田長次郎が，自邸として新田家の建築顧問でもあった 近代建築家・木子七郎に本館の設計を依頼したものである ${ }^{16}$ 。本 館は昭和 3 年の竣工であった ${ }^{16)}$ 。

庭園は，芝庭に噴水池を設けた本館南の洋風庭園，池に中島を 配した本館東の和風庭園を主要構成とする。ここでも, 庭園内の 円卓や腰掛け, アーチ, 袖垣などの庭園施設に擬木を導入してい る。特に注目されるのは, 敷地東端に建つ防空壕と一体的に造成 された築山に配置・構成されている擬石群である (図一5)。擬石 は温山荘庭園と同様に，表面調整としてモルタルを塗着して整形 しているが，モルタルに染料を混加せず，ペンキと思しき塗料で 着色した点が温山荘とは異なる。現状では，風化による塗料の剥 落があるものの, 残存部分は緑色の塗料で着色されていることが 確認できた。これは，新田の故郷が伊予青石を産出する松山であ ったこと, 温山荘を造営した地域が紀州青石を産出する和歌山で, 実際庭園内に青石を模造した擬石を用いていた ${ }^{6}$ ことから考える と, 甲子園の本庭園の緑色に着色した擬石も，青石を模造したも のと指摘できる。そして，自ら擬石の製作とともに作庭もおこな っていた新田自身の別荘・温山荘や新田帯革製造所北海道十勝工 場での取り組み 17) を考慮すると，甲子園の旧新田邸庭園につい

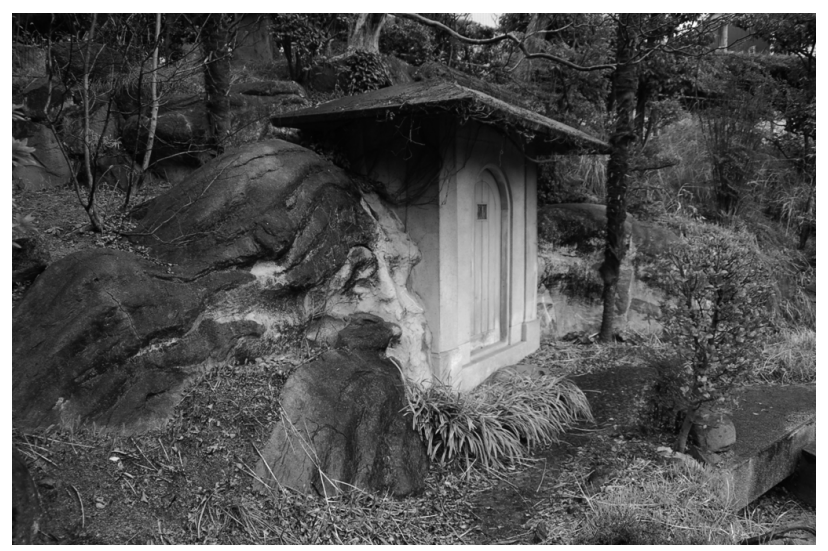

図-5＼cjkstart西宮・甲子園の旧新田邸庭園の擬石（防空壕脇） (平成 21 年 3 月 3 日撮影) 
ても，新田本人が作庭を主導したものと推定できる。

したがって庭園の築造年代は，本館が竣工した昭和 3 年と同時 期か, 時期が下っても新田が没する昭和 11 年 18 ) 以前であったと 考えられ，本庭園は椎原らとは異なる経緯で擬木・擬石が導入さ れた近代の現存事例として注目される。

\section{（4）大阪市内の公園空間への擬木 · 擬石 ·擬岩の多様な展開}

大阪市内の公園においては，昭和 5 年以前に扇町公園に橋本八 重三が大阪市公園課の依頼によって擬木を導入していた（表一2）。 その後, 昭和 6 年の桜宮公園と大阪城公園, 昭和 7 9 年の天王 寺公園およひ動物園の拡張あるいは改造工事にともない，擬木・ 擬石・擬岩が公園空間に導入されていったことが，表一 3 に示し た各種文献から確認できる。これは大正 15 年に中沢考から擬木 を勧められた椎原兵市が，大阪市公園課長として実際の公園建設 の中心的役割を担っていたことによるのであろう。

表一3の文献「い〜り」の記述内容の分析にもとづき，各公園 に設置された擬木・擬石・擬岩施設を一覧として整理した（表一 4）。これらのうち, 桜宮公園の擬木橋梁, 大阪城公園の 2 ヶ所の 擬木藤棚, 天王寺公園擬石滝石組 (現・天王寺動物園内) (図一6), 天王寺動物園猿ヶ島擬岩（図一7）は，芦屋で造園業を営んでい た小林観山が椎原兵市の指導のもと，手掛けたもの7) である。

表一4の橋梁や藤棚といった擬木施設, 白熊檻や猿ヶ島といっ た擬岩施設は，構造は「鉄筋コンクリート造」あるいは「コンク リート造」とあるが，文献に「コンクリート造」の記載のある大 阪城公園のふたつの藤棚と天王寺公園の藤棚と庭橋といった擬木

\section{表－3 大阪市内の公園・動物園に二擬木・擬石・擬岩が} 導入されたことを示す文献一覧

\begin{tabular}{|c|c|c|c|}
\hline 記 号 & 著者名 & 発行年 & 書名·雑誌名 \\
\hline い & 橋本八重三 & 昭和5年 & 『植木屋の裏扰もて』(六合館) \\
\hline ろ & 牧岡信四郎 & 昭和7年 & 紀州御殿と山里丸の庭園 (「庭園と風景」第14巻第2号所収) \\
\hline は & 横山三四次 & 昭和7年 & 大阪城公園の工作物解説 (「庭園と風景 $]$ 第 14 巻第 2 号所收) \\
\hline$に$ & 方米治郎 & 昭和7年 & 桜宫公園の拡張工事(「庭園と風景」第14巻第3号所収) \\
\hline ほ & 菊名達也 & 昭和7年 & 混凝土擬木について (「庭園と風景」第 14 巻第 4 号所収) \\
\hline へ & 不詳 & 昭和9年 & 天王寺公園グラフ(「建築と社会」第17輯4号所収) \\
\hline と & 椎原兵市 & 昭和9年 & 天王寺公園の沿革と全貌（「建築と社会」第17輯4号所収） \\
\hline$\hbar$ & 方米治郎 & 昭和9年 & 天王寺公園の改造工事(「建築と社会」第 17 輯 4 号所収) \\
\hline り & 小林観山 & 昭和 41 年 & $\begin{array}{l}\text { 椎原さんと擬木擬石作り (『椎原兵市氏の作品と業績』所収) } \\
\text { (椎原兵氏績と作品出版委員会) }\end{array}$ \\
\hline
\end{tabular}

施設についても，強度面の問題から鉄筋コンクリート造としてい た可能性がある。また擬岩については，猿ヶ島の施工を担当した 小林観山によれば，まず椎原と小林で石膏による模型製作で検討 をおこない，実施工程は鉄骨鉄筋による骨組製作，ラス張りから モルタル塗着とす寸め, 表面は色モルタルを塗着し, 岩山として

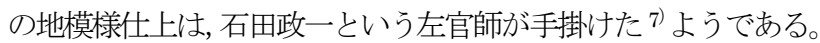

上記の公園空間に導入された各施設の特徵は，桜宮公園の全長 34 尺（約 $10.2 \mathrm{~m}$ ）の擬木橋梁，天王寺公園の全長 $45 \mathrm{~m}$ の和気橋 や梁間 $84 \mathrm{~m}$ の長大な擬木藤棚, 天王寺動物園の岩床面 $180 \mathrm{~m}^{2} の$ 白熊檻の擬岩など，住宅・別荘庭園のものからは明らかに巨大化 した擬木・擬石・擬岩施設を具現化した点にある。そして，表面 に自然石のごとく筋目を入れつつも角張つた凹凸を付し、緑色片 岩の自然石にモルタルを塗着して擬石を構成した天王寺公園の滝 石組，動物園では，階段状に岩床を造成しつつ，直線の屈曲を活 かした意匠と白色モルタルで化粧することによって氷岩を劇的に 表現した白熊檻，鏝や箟のような工具で整形した擬岩によって岩 山が屹立する様子をダイナミックに構成した高さ $8 \mathrm{~m}$ におよぶ猿 ケ島など，特に擬石・擬岩は，精緻な整形技術に裹打ちされた豪 快な表現を造形意匠上の特徴とするものであったと指摘できる。

なお，大阪城公園内の各種工作物を手掛けた業者に稲垣徳次郎 （稲垣工業所）がいたが，「庭園と風景」第 14 巻第 2 号 19) の会 社広告には「造園用石材」として「各種擬石工芸品」という記載 がある。このことから，稲垣の手掛けた擬石施設も大阪市内の造 園空間に利用されていた可能性も本稿では考えておきたい。

\section{4. おわりに}

以上，近代の大阪および阪神間を中心とした擬木・擬岩・擬石 の導入と展開については，次のようなことが明らかとなった。 イ，擬木の導入は，大正 15 年頃にキューバから帰国した中沢考 が椎原兵市にその利用を勧め, 椎原が橋本八重三にこれを紹介し たことを端緒とする。また同時期に横浜の野毛山公園の擬木にヒ ントを得て，小林観山も擬木の試作に着手していた。したがって 当該地域では、大正 15 年頃に椎原・橋本・小林の 3 人の造園家・ 造園技術者を中心に擬木製作が開始された。

口，擬木の住宅・別荘庭園の流布には，さまざまな擬木製庭園家 具を考案した「橋本式人造自然木」の商品化がその役割の一端を

表-4 擬木 - 擬石 · 擬岩か確認された大阪市内の公園 - 動物園

\begin{tabular}{|c|c|c|c|c|c|c|c|}
\hline 名 称 & 擬木·擬石・擬岩施設 & 建設年代 & 構 造 & 仕 上 & 規 模 & 現存 & 根 拠 \\
\hline 扇町公園 & 人造自然木製品 (詳細工作物不詳) & 昭和5年以前 & 不詳 & 不詳 & 不詳 & 不詳 & 文献「い」 \\
\hline 桜宮公園 & $\mid \begin{array}{l}\mid \text { 擬木橋梁 } \\
\text { 擬木藤棚 } \\
\text { 池泉護岸擬木乱杭 }\end{array}$ & \begin{tabular}{|l} 
昭和6年 \\
昭和6年 \\
昭和6年
\end{tabular} & $\begin{array}{l}\text { 鉄筋コンクリート造 } \\
\text { 鎙コンクリート造 } \\
\text { コンクリート造 }\end{array}$ & \begin{tabular}{|l} 
橋台:モルタル木皮仕上 \\
高欄: モルタル自然木仕上 \\
擬木仕上 \\
不詳
\end{tabular} & $\begin{array}{l}\text { 全長: } 34 \text { 尺 } \\
\text { 幅員: } 12 \text { 尺 } \\
\text { 桁行:6間×梁間: } 2 \text { 間 } \\
\text { 高さ: } 10 \text { 尺 }\end{array}$ & $x$ & $\begin{array}{l}\text { 文献「に」 } \\
\text { 文献「に」 } \\
\text { 文献「に」 }\end{array}$ \\
\hline 大阪城公園 & $\begin{array}{l}\text { 池泉護岸擬木乱杭(紀州御殿庭園) } \\
\text { 擬木藤棚(山里丸北西隅) } \\
\text { 擬木藤棚 (貯水池東) }\end{array}$ & \begin{tabular}{|l|} 
昭和6年 \\
昭和6年 \\
昭和6年
\end{tabular} & \begin{tabular}{|l} 
コンクリート造 \\
コンクリート造 \\
コンクリート造 \\
鉄筋コンクリート造か?
\end{tabular} & $\begin{array}{l}\text { モルタル塗り皮付丸太仕上 } \\
\text { 不詳 } \\
\text { 擬木仕上 } \\
\text { モルタル塗り模擬木材木目入仕上 }\end{array}$ & & $\begin{array}{l}0 \\
\times \\
0\end{array}$ & $\begin{array}{l}\text { 文献「ろ」 } \\
\text { 文献「は」「ほ」 } \\
\text { 文献「は」「ほ」 }\end{array}$ \\
\hline 天王寺公園 & \begin{tabular}{|l} 
入口門(茶臼山西) \\
擬木橋梁(和気橋) \\
擬木藤棚 (運動場西) \\
擬石滝石組 (日本庭園、現·天王寺動物園) \\
擬木藤棚 (日本庭園、現・天王寺動物園) \\
擬木庭橋 (日本庭園、現·天王寺動物園) \\
擬木腰掛 \\
擬木電柱
\end{tabular} & \begin{tabular}{|l} 
昭和 $7 \sim 9$ 年 \\
昭和7 9年 \\
昭和7 9年 \\
昭和 8 年 \\
昭和 7 9年 \\
昭和 $7 \sim 9$ 年 \\
昭和 $7 \sim 9$ 年 \\
昭和 $7 \sim 9$ 年
\end{tabular} & $\begin{array}{l}\text { 鉄筋コンクリート造 } \\
\text { 橋体:鉄筋コンクリート造 } \\
\text { 勾欄:造 } \\
\text { 柱·柠·梁:鉄筋コンクリート造 } \\
\text { 栈木:木造 } \\
\text { 自然石及びコンクリート造 } \\
\text { コンクリート造 } \\
\text { コンクリート造 } \\
\text { 地覆鉄筋コンクリート造 } \\
\text { 鉄筋コンクリート造 }\end{array}$ & $\begin{array}{l}\text { モルタル刷毛引擬木丸太仕上 } \\
\text { 橋脚·析·梁·橋面:着色モルタル擬木仕上 } \\
\text { 柱·桁·梁:着色モルタル擬木仕上 } \\
\text { モルタル塗り擬石仕上 } \\
\text { 擬木仕上 } \\
\text { モルタル叙り模擬木材木目入仕上 } \\
\text { 皮付自然木仕上 } \\
\text { 着色モルタル擬木仕上 }\end{array}$ & \begin{tabular}{|l} 
幅: $: 2.4 \mathrm{~m}$ \\
高さ: $2.2 \mathrm{~m}$ \\
全長: $45 \mathrm{~m}$ \\
幅員: $3.3 \mathrm{~m}$ \\
中央舞場幅員: $: 5.3 \mathrm{~m}$ \\
析行 $: 3.6 \mathrm{~m} \times$ 梁間: $84 \mathrm{~m}$ \\
高さ: $2.7 \mathrm{~m}$
\end{tabular} & $\begin{array}{l}\times \\
0 \\
\times \\
\times \\
0 \\
x\end{array}$ & $\begin{array}{l}\text { 文献〔へ」 } \\
\text { 文献〔へ」 } \\
\text { 文献「へ」 } \\
\text { 文献〔へ」り」 } \\
\text { 文献「ち」 } \\
\text { 文献「ち」 } \\
\text { 文献「と」 } \\
\text { 文献「と」 }\end{array}$ \\
\hline 天王寺動物園 & $\begin{array}{l}\text { 白熊檻擬岩 (水岩および岩壁) } \\
\text { 猿ヶ島擬岩(摸擬山岳) } \\
\text { 猿ヶ島擬木製丸太小屋 }\end{array}$ & \begin{tabular}{|l} 
昭和7 9年 \\
昭和9年 \\
昭和9年
\end{tabular} & $\begin{array}{l}\text { 鉄筋コンクリート造 } \\
\text { 鉄骨鉄筋コンクリート造ラス張り } \\
\text { 鉄筋コンクリート造 }\end{array}$ & \begin{tabular}{|l|} 
モルタル塗り擬岩仕上 \\
着色モルタル刷毛引仕上 \\
モルタル塗り皮付丸太仕上
\end{tabular} & $\begin{array}{l}\text { 水岩床面積: } 180 \mathrm{~m}^{2} \\
\text { 岩壁高さ: } 3.1 \mathrm{~m} \\
\text { 高さ: } 8 \mathrm{~m}\end{array}$ & $\begin{array}{l}0 \\
0\end{array}$ & \begin{tabular}{|l} 
文献「へ」 \\
文献「一」「ち」 \\
文献「へ」
\end{tabular} \\
\hline
\end{tabular}

註: 各欄の記載事項は、文献「い〜り」の記述を根拠とする。また、ゴシック体の表記(「公園名称」欄を除く)は、筆者による現地観察での所見を示す。現存」欄の○印は、現地調査で現存を確認したも の、×印は確認できなかったものを示す 



図ー7 椎原兵市の指導により小林観山が施エした 天王寺動物園猿ヶ島 (平成 22 年 2 月 3 日撮影)

担った。昭和 2 年の段階では商品化がなされており，当時橋本は 橋本庭園装飾店工房を設立し，当工房で製作をおこなっていた。 八, 大阪では，昭和 6 年から 9 年にかけて，市内の公園や動物園 に擬木・擬石・擬岩が導入された。特に，天王寺公園の擬石滝石 組，天王寺動物園の猿ヶ島など造形的に水準の高いものは，椎原 の指導のもと，小林観山が製作の実際にあたつたものであった。 二，阪神間の擬木・擬石を導入した事例では，実業家・新田長次 郎が作庭を主導したと考えられる甲子園の旧新田邸庭園が確認で きた。アーチや円卓などに擬木製庭園家具を多用し，築山の石組 には緑色に表面を塗装し, 青石を模したような擬石が用いられた。

このように大阪および阪神間では，多様な擬木・擬石・擬岩に よる造園空間が近代に誕生したが，橋本式人造自然木はその現存 事例が確認できておらず，表一 4 で示したように大阪市内の擬 木・擬石・擬岩施設も多くのものが失われたことが判明した。た だし，旧新田邸庭園，擬石で滝石組を構成した天王寺公園の日本 庭園, 天王寺動物園猿ケ島や白熊檻などの現存事例も確認できた。 現存事例について保存に向けた価值を見出していくには，むろん 各種造園空間の性格や所有者の意向もふまえて検討しなければな らないが，日本造園学会がまとめた「近代ランドスケープ遺産の 保全に関する提言」(平成 18 年 9 月 30 日）20）における重要な課 題, すなわち「近代ランドスケープ遺産に関する目録の作成推進」
に向けた知見の一端は，本稿で提供できたと考える。

今回判明した現存事例は，表面調整に精緻な技巧を施すもので ある。旧新田邸庭園の擬木・擬石は，本物に似せようと写実性に 配慮したもので，とりわけ築山の擬石は一瞥すると自然石と見間 違うものである。しかしそれは本物とは明らかに深すぎる㱀が彫 られ，大きなうねりを具備した稜線を整形寸るなど，本物をふま え劇的な造形を特色とするものである。また，公共造園の擬石・ 擬岩は豪快かつ大胆な造作によって本来の山や滝の姿・形を意図 的にデフォルメしたものとも見受けられた。木・石・岩に「擬え る」という行為においては、「材料の真, 構造の真」1)にそむいた 「似せ物」(偽物) であるが故に，「本物から飛躍した劇的・誇張 的造形」を志向する感性が近代には存在したと現段階では解釈し ておくべきだろうか。この是非については，同時期に擬木・擬石・ 擬岩が流布した東京 ${ }^{6}$ およびその他の地域の事例も多く収集して 擬木・擬石・擬岩の導入と展開に関する歴史を明らかにしつつ, 技術・造形意匠の系譜をまとめることによって検証できると考え る。そのうえで技術史的な画期となる現存事例や造形意匠として 傑出した現存事例などの明確化を試みていきたい。そして近代ラ ンドスケープ遺産の保全に有用な知見を少しでも多く提示したい。

謝辞 : 本研究をすすめるにあたり, 貴重なご意見・ご助言をい ただいた大阪芸術大学教授・若生謙二先生, 東京農業大学教授・ 小林章先生，ならびに現地調査にご配慮いただいた松山大学，大 阪市天王寺動植物公園事務所，大阪府教育委員会，大阪市教育委 員会のみなさまに感謝申し上げます。

\section{補注及び引用文献}

1）上原敬二 (1969)：『岩石・庭石・石組方法』：加島書店

2）文化庁文化財部監修（2010）: 琴ノ浦温山荘庭園：「月刊文化財」平 成 22 年 2 月号 : 第一法規

3) 平澤毅 (2010):『文化的資産としての名勝地』:科学研究費補助金 課 題番号：19589004 基盤研究 (C)「文化的資産としての名勝地の概 念及びその適用に関する基礎的研究」（平成 19 年度〜平成 21 年度) 報告書

4）近藤三雄 (2009) : わが国における屋上庭園の起源と黎明期における 展開について : 造園技術報告集（5）,200-203

5）橋爪紳也（1995）：田園都市の職人 橋本八重三 :『にぎわいを創る 近代日本の空間プランナーたち』所収 : 長谷工総合研究所

6) 粟野隆 (2009) : 擬石・擬木の造園的利用の系譜からみた琴ノ浦温山 荘園の造園史的位置づけについて : ランドスケープ研究 72 (5) ,439-442

7）小林観山（1966）：椎原さんと擬木擬石作り：『椎原兵市氏の作品と 業績』所収 : 椎原兵市氏の業績と作品出版委員会

8）椎原兵市氏の業績と作品出版委員会 (1966) : 年譜 :『椎原兵市氏の 作品と業績』所収 : 椎原兵市氏の業績と作品出版委員会

9）村松善豊（1979）：擬木擬石松村重について：『緑の東京史』所収： 思考社

10）椎原兵市（1928）:『庭園の設計と其実例』: 雄山閣

11）前掲 6) の報告では, 椎原兵市が『庭園の設計と其実例』で擬木を導 入した庭園事例は 9 件とあったが，精査の結果 10 件であったことを 確認した。

12）橋本八重三 (1930) : 『植木屋の裏おもて』: 六合館

13）橋本庭園工務所（発行年不詳）：『庭園の設計・施工案内』: カタログ の記載内容力ら，昭和 7 年頃の発行と思われる。

14） 渡辺泰輔編（1927）:『全国著名園芸家総覧』(初版）: 大阪興信社

15）渡辺泰輔編 (1938) : 『全国著名園芸家総覧』(第 14 版) : 大阪興信社

16）兵庫県教育委員会事務局文化財室 (2006) : 兵庫県の近代化遺産 兵 庫県近代化遺産（建造物等）総合調査報告書

17）新田長次郎（1935）: 『回顧七十有七年』: 合資会社新田革帯製造所

18）奈良文化財研究所編（2009）:『琴ノ浦温山荘園庭園調查報告書』: 琴 ノ浦温山荘園

19）稲垣工業所会社広告（1932）: 庭園と風景 14 （2）所収

20) 日本造園学会ランドスケープ遺産研究委員会 (2007) : 近代ランドス ケープ遺産の保全に関する提言:ランドスケープ研究 70 (4), 281-286 